\title{
PEMANFAATAN LIMBAH BOTOL PLASTIK MENJADI PLASTICNET SEBAGAI BAHAN SEPARASI DAN PERKUATAN PADA LAPISAN PERKERASAN JALAN RAYA DI DAERAH TERPENCIL
}

\author{
Dedy Dharmawansyah ${ }^{1}$, Eti Kurniati ${ }^{2}$ \\ ${ }^{12}$ Program Studi Teknik Sipil Fakultas Teknik, Universitas Teknologi Sumbawa. \\ *Corresponding author. E-mail: dedy.dharmawansyah@uts.ac.id
}

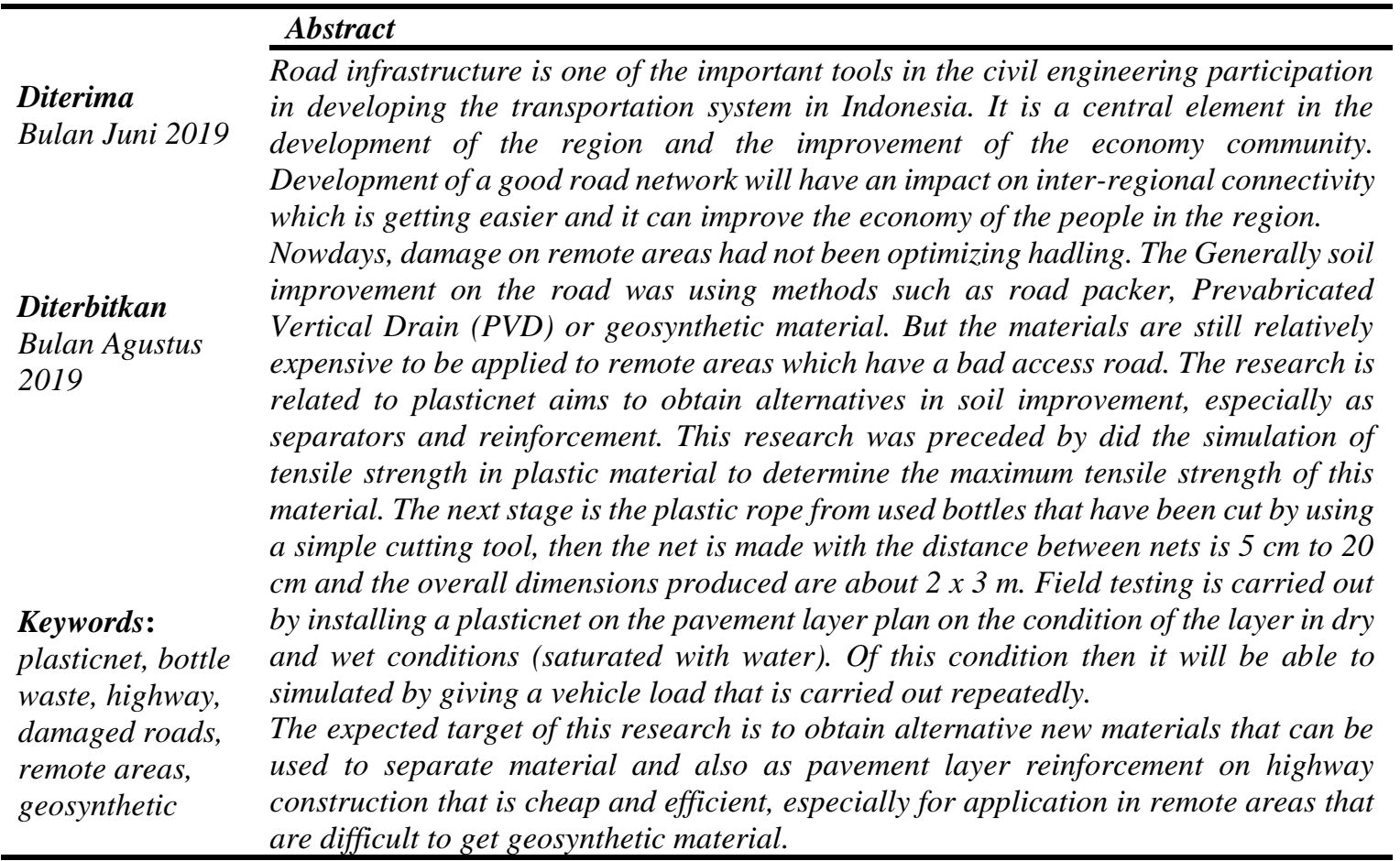

\section{PENDAHULUAN}

Infrastruktur jalan merupakan salah satu sarana penting dalam dunia teknik sipil yang berperan dalam pengembangan sistem transportasi di Indonesia. Infrastruktur jalan menjadi unsur sentral dalam pengembangan wilayah dan peningkatan perekonomian masyarakat. Pembangunan jaringan jalan yang baik akan memberikan dampak pada konektivitas antar wilayah yang semakin mudah dan juga dapat meningkatkan perekonomian masyarakat di wilayah tersebut. Undang-undang No. 38 Tahun 2004 menjabarkan tiga peran jalan diantaranya:

1. Sebagai bagian dari prasarana transportasi mempunyai peran penting dalam ekonomi, sosila dan budaya, pertahanan dan keamanan dan lingkungan hidup serta wajib dipergunakan untuk sebesar-besar kemakmukaran rakyat,

2. Sebagai prasarana distribusi barang dan jasa merupakan urat nadi kehidupan masyarakat bangsa dan negara,

3. Sebagai satu kesatuan sistem jaringan jalan mengikat seluruh wilayah Republik Indonesia.

Berdasarkan Informasi Statistik Infrastruktur yang dikeluarkan oleh Kementerian Pekerjaan Umum dan Perumahan Rakyat pada tahun 2015 menunjukkan bahwa jalan nasional sudah terkoneksi di seluruh wilayah Indonesia sepanjang 38.569,82 $\mathrm{km}$ dengan permukaan jalan dalam kondisi baik sepanjang 23.913,60 km (62\%), dalam kondisi sedang sepanjang $12.320,97 \mathrm{~km}(31,94 \%)$, dalam kondisi rusak ringan sepanjang 1.204,36 km (3,12\%), dalam kondisi rusak berat sepanjang $1.130,90 \mathrm{~km}$ $(2,93 \%)$.

Di wilayah Nusa Tenggara Barat, berdasarkan data dari Badan Perencanaan Pembangunan Daerah bekerja sama dengan Badan Pusat Statistik Propinsi Nusa Tengara Barat tahun 2015 menjelaskan bahwa, jalan nasional yang sudah dibangun sampai tahun 2014 sepanjang 632,17 km dengan kondisi baik sepanjang 578,94 km, sedang sepanjang $54,17 \mathrm{~km}$, rusak ringan sepanjang $0,86 \mathrm{~km}$ dan rusak berat sepanjang $0,20 \mathrm{~km}$. Sedangkan untuk jalan propinsi yang sudah dibangun sampai tahun 2014 sepanjang $1.772,27 \mathrm{~km}$ dengan permukaan jalan yang sudah diaspal sepanjang $1.438,79 \mathrm{~km}$, permukaan kerikil sepanjang $123,10 \mathrm{~km}$, permukaan tanah sepanjang $76,18 \mathrm{~km}$ dan yang tidak dirinci sepanjang 134,20 $\mathrm{km}$. Sedangkan kondisi jalan propinsi dalam keadaan baik sepanjang 749,16 km (42,27\%), keadaan sedang sepanjang $473,49 \mathrm{~km}(26,71 \%)$, keadaan rusak ringan sepanjang $111,35 \mathrm{~km}(6,28 \%)$, keadaan rusak 
berat sepanjang $304,07 \mathrm{~km}(17,16 \%)$ dan tidak dirinci sepanjang $134,20 \mathrm{~km}(7,57 \%)$. Berdasarkan data ini, kerusakan jalan masih menjadi permasalahan serius yang harus diatasi baik oleh pemerintah pusat maupun pemerintah daerah. Dengan adanya kerusakan jalan, pemerintah harus mengeluarkan dana yang besar untuk pemeliharaan ruas-ruas jalan baik pemeliharaan rutin maupun pemeliharaan lainnya.

Kerusakan Jalan yang terjadi di Indonesia khususnya di wilayah NTB seperti yang djabarkan diatas dapat disebabkan oleh berbagai macam faktor diantaranya beban lalu lintas yang lebih besar dari yang direncanakan, pelaksanaan dilapangan yang tidak sesuai dengan persyaratan yang ditentukan, daya dukung tanah yang ada tidak mampu menahan beban yang menyebabkan terjadinya kerusakan dini dan bisa juga disebabkan oleh kondisi drainase yang yang buruk. Dari berbagai faktor penyebab ini, kerusakan jalan akibat daya dukung tanah menjadi permasalahan yang akan dibahas pada penelitian ini. Penurunan daya dukung tanah dapat disebabkan oleh kondisi tanah eksisting yang buruk (tanah lunak, tanah ekspansif, tanah clayshale dan lain-lain) dan dapat juga disebabkan oleh pemadatan tanah dilapangan yang tidak maksimal sehingga menyebabkan kemampuan tanah dalam menerima beban menjadi tidak sesuai yang ditargetkan.

Dewasa ini, berbagai metode perbaikan tanah untuk permasalahan daya dukung tanah eksisting sudah banyak dikembangkan seperti penggunaan Road Packer, Prevabricated Vertical Drain (PVD) yang dikombinasikan dengan Preloading dan penggunaan geosintetik. Namun penggunaan berbagai metode perbaikan tanah diatas masih sulit di aplikasikan pada daerah-daerah terpencil, khususnya pada daerah dengan akses jalan rusak berat yang jauh dari perkotaan dan juga pada daerah dalam tahap pembukaan jalan baru. Hal ini disebabkan karena metode ini masih tergolong mahal baik dari segi harga maupun transportasi bahan dan alat berat menuju lokasi.

Berdasarkan permasalahan diatas diperlukan bahan lain, dimana dari segi ketersediaan bahan baku mudah diperoleh dan biaya produksi yang terjangkau. Penggunaan Plasticnet sebagai salah satu bahan untuk melakukan perbaikan tanah (sebagai bahan pemisah/separasi dan perkuatan) pada lapisan perkerasan jalan menjadi alternatif yang dapat dilakukan untuk mengganti penggunaan bahan geosintetis khususnya geotekstil dan geogrid. Plasticnet ini berasal dari limbah botol plastik yang potong (strip) menggunakan peralatan sederhana hingga menjadi tali plastik yang selanjutnya di anyam menyerupai jaring-jaring.

Diharapkan dengan adanya pemanfaatan limbah botol plastik menjadi plasticnet sebagai bahan pemisah lapisan perkerasan jalan raya ini dapat menjadi alternatif perbaikan tanah untuk mengganti penggunaan geogrid khususnya didaerah-daerah terpencil sehingga biaya produksi dan pelaksanaan dapat diminimalisir.

\section{METODE PENELITIAN}

\section{Rancangan Penelitian}

Kemampuan dominan pada material ini direpresentasikan dalam bentuk kekuatan tarik. Pengujian kuat tarik akan dilakukan sesuai dengan ketentuan yang sudah ditetapkan dalam ASTM D638 "Standard Test Method for Tensile Properties of Plastic".

Bahan baku plasticnet berasal dari jenis polimer polyethylene (PET/PETE) yang berkode 1 sedangkan polypropylene (PP) yang berkode 5 pada kemasan produknya.

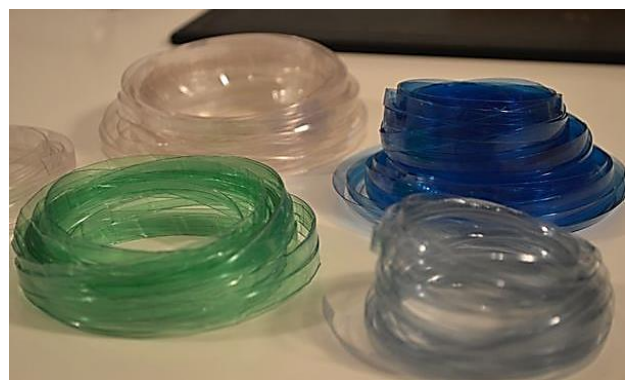

Gambar 1. Tali plastik dari limbah botol

Botol plastik selanjutnya dibuat menyerupai tali dengan lebar sekitar 5-10 mm (Gambar 1). Perakitan tali menjadi jaring plastik dilakukan secara vertikal dari atas kebawah dengan bantuan kayu penggantung yang sudah dilengkapi dengan paku-paku sebagai penanda jarak antar lubang pada jaring. Konsep perakitan tali menjadi jaring plastik (plasticnet) dapat dilihat pada Gambar 2.

Plasticnet yang sudah terbentuk selanjutnya dihamparkan pada rencana lokasi jalan raya. Setelah lapisan perkerasan tersusun, maka selanjutnya akan dilewati kendaraan secara berulang berupa truk atau mobil penumpang sebagai beban kendaraan.

Dari hasil ini, selanjutnya dilakukan pengamatan terhadap kondisi material mulai dari kondisi setelah dihamparkan batu pecah dan timbunan untuk mengetahui ketahanan material terhadap robek.

Disamping itu, pengamatan juga dilakukan pada kondisi setelah material ini dibebani baik oleh timbunan maupun beban kendaraan dalam kondisi kering maupun kondisi basah untuk mengetahui pengaruh perubahan temperatur pada material plasticnet. Dari hasil pengujian selanjutnya disimpulkan kehandalan material plasticnet. 
JURNAL TAMBORA VOL. 3 NO. 2 JUNI 2019

http://jurnal.uts.ac.id

Science and Technology

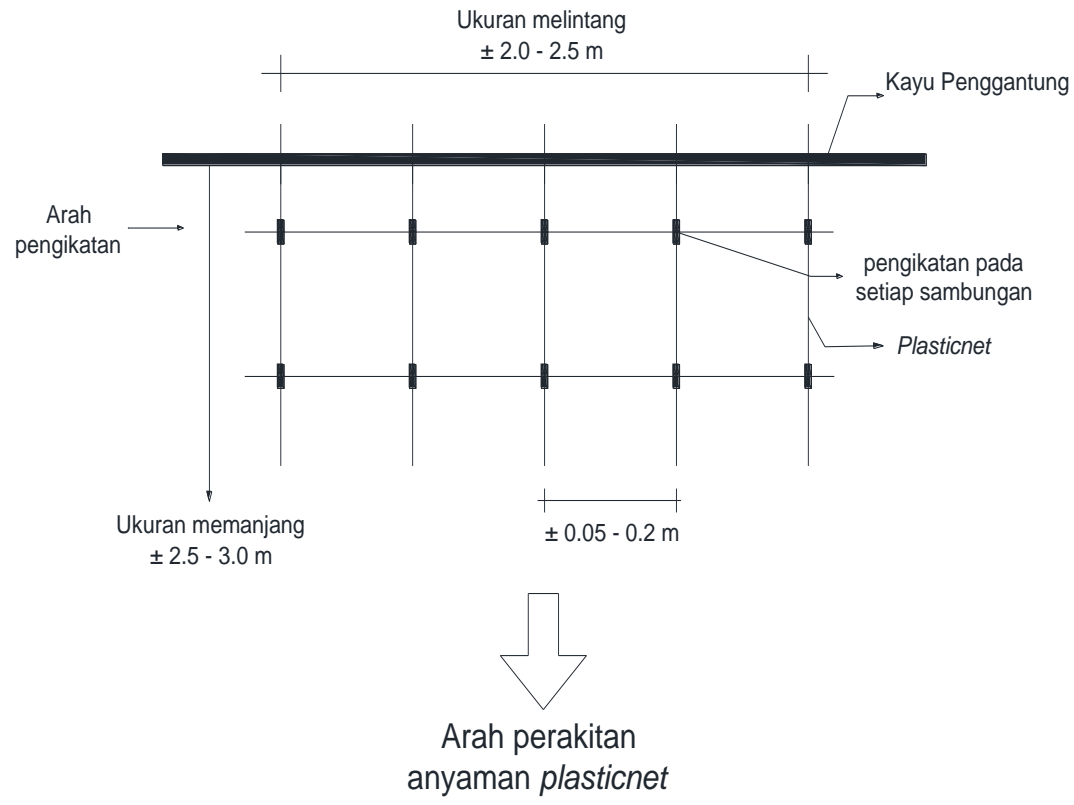

Gambar 2. Konsep perakitan tali menjadi Plasticnet

\section{Tahapan Penelitian}

Penelitian ini diawali dengan identifikasi masalah dengan mengamati banyaknya kerusakan jalan diwilayah NTB khususya pada daerah terpencil yang disebabkan oleh banyak faktor, salah satunya adalah mahalnya material perbaikan tanah yang digunakan. Berdasarkan permasalahan tersebut maka dilanjutkan pada langkah berikutnya melalui studi literatur untuk mengetahui penyebab, langkah penanganan dan material perbaikan yang tepat berdasarkan sumber keilmuan.

Pada tahapan selanjutnya dilakukan pemilihan bahan plastik dari botol bekas berdasarkan jenis kemasan yang sudah tertera pada bagian kemasannya. Dalam hal ini jenis material plastik yang digunakan yaitu dari jenis polimer polyethylene (PET/PETE) yang berkode 1 dan polypropylene $(\mathrm{PP})$ yang berkode 5 . Untuk memastikan kehandalan produk ini, maka pada tahapan berikutnya dilakukan pengujian tarik bahan plastik ini menggunakan bantuan software ANSYS, dari tahapan ini dapat diketahui deformasi material setelah diberikan beban tarik. Apabila tidak memenuhi syarat maka dilakukan pemilihan bahan dari jenis lainnya. Namun apabila sudah memenuhi syarat deformasi, maka material ini dapat digunakan untuk pembuatan plasticnet.

Tahapan berikutnya berupa pengujian lapangan, dengan susunan material mulai dari bawah berturutturut adalah Lapisan tanah dasar, plasticnet, batu pecah dan material tanah (timbunan). Setelah semua lapisan dihamparkan, selanjutnya dilakukan pemadatan dan penerapan beban berupa beban kendaraan+muatan. Langkah terakhir yaitu mengamati kondisi fisik dari material ini setelah dilakukan pembebanan. Diagram Alir penelitian dapat dilihat pada Gambar 3. 


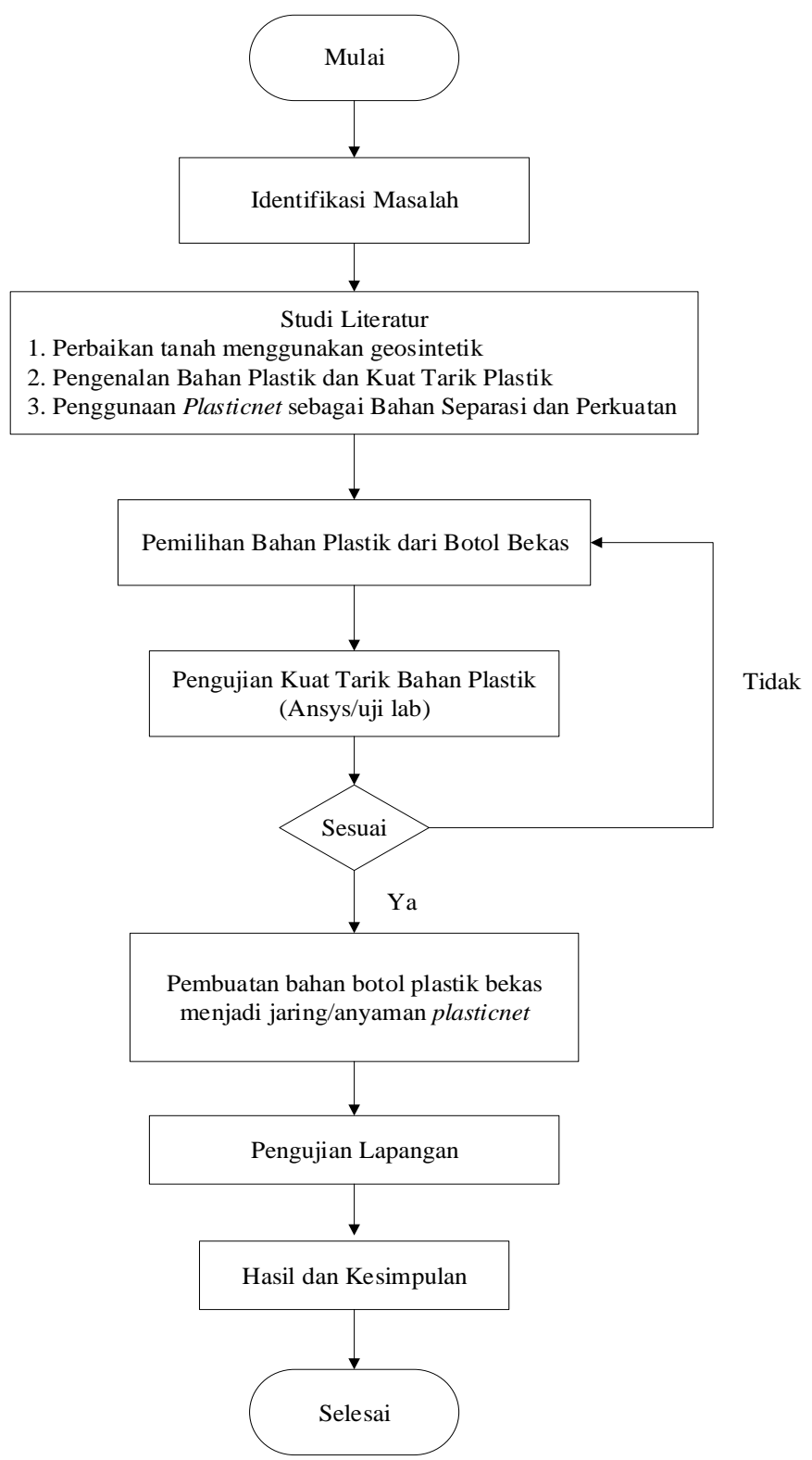

Gambar 3. Diagram alir penelitian

\section{HASIL DAN PEMBAHASAN}

\section{Simulasi Kuat Tarik}

Pengujian kekuatan tarik bahan plastik di simulasikan menggunakan bantuan software Ansys dengan memasukkan properti material plastik yang digunakan seperti Tabel 1 berikut.

Tabel 1. Properti Material Plastik

\begin{tabular}{|l|c|}
\hline Density & $1070 \mathrm{~kg} / \mathrm{m}^{3}$ \\
\hline $\begin{array}{l}\text { Iso. Secant Coeff. of Thermal } \\
\text { Exp. }\end{array}$ & $1.05 \mathrm{E}-6 / \mathrm{K}$ \\
\hline $\begin{array}{l}\text { Specific Heat Constant } \\
\text { Pressure }\end{array}$ & $434 \mathrm{~J} / \mathrm{kg}-\mathrm{C}$ \\
\hline Iso. Thermal Conductivity & $60.5 \mathrm{~W} / \mathrm{m}-\mathrm{C}$ \\
\hline Isotropiic Resistivity & $1.7 \mathrm{e}-007 \mathrm{ohm} \mathrm{m}$ \\
\hline Young Modulus & $2.2477 \mathrm{e}+009 \mathrm{~Pa}$ \\
\hline Bulk Modulus & $7.4923 \mathrm{e}+008 \mathrm{~Pa}$ \\
\hline Shear Modulus & $1.1238 \mathrm{e}+009 \mathrm{~Pa}$ \\
\hline
\end{tabular}

\begin{tabular}{|l|c|}
\hline Tensile Ultimate Strength & $50 \mathrm{MPa}$ \\
\hline Force & $10000 \mathrm{~N}$ \\
\hline
\end{tabular}

Hasil simulasi kuat tarik pada limbah botol plastik menunjukkan bahwa deformasi total sebesar 0.015294 m, Maximum Shear Elastic Strain sebesar $0.01112 \mathrm{~m} / \mathrm{m}$ dan Maximum Shear Stress sebesar $1.2497 \mathrm{e} 7 \mathrm{~Pa}$. Dari penerapan gaya sebesar $10000 \mathrm{~N}$ $\approx 10 \mathrm{kN}$ dihasilkan deformasi total sebesar 0.015294 $\mathrm{m} \approx 1.53 \mathrm{~cm}$ (perkiraan kondisi putus). Sehingga berdasarkan simulasi ini, bahan limbah botol plastik memungkinkan untuk digunakan sebagai bahan plasticnet. Hasil simulasi menggunakan software Ansys dapat dilihat pada Gambar 4, Gambar 5 dan Gambar 6. 
JURNAL TAMBORA VOL. 3 NO. 2 JUNI 2019

http://jurnal.uts.ac.id

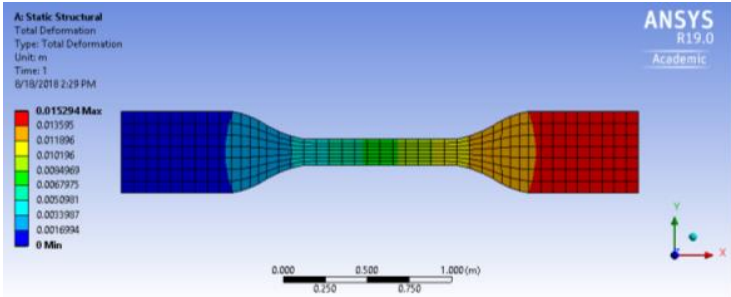

Gambar 4. Total deformation plasticnet

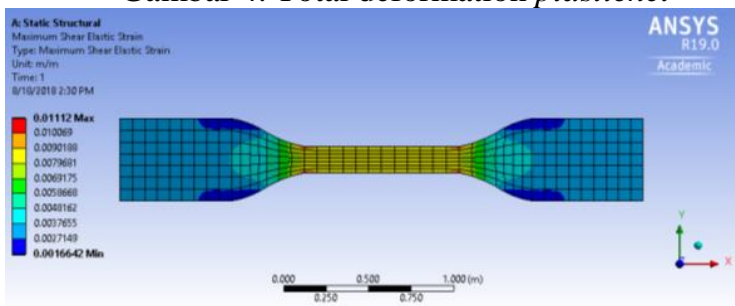

Gambar 5. Maximum shear elastic strain plasticnet

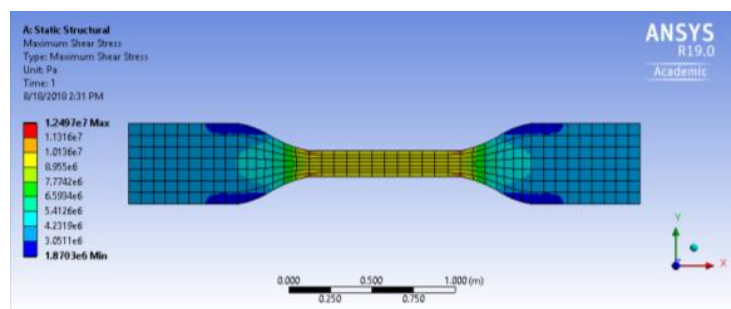

Gambar 6. Maximum shear stress plasticnet

\section{Tali Botol Plastik}

Tali botol plastik dibuat menggunakan alat pemotong sederhana (Gambar 7) dengan ketebalan pemotongan yang dapat diatur sesuai dengan kebutuhan dan ukuran material yang akan dihamparkan pada lapisan jalan. Pada penelitian ini, tali plastik dipotong dengan ukuran $1 \mathrm{~cm}$, ketebalan bervariasi antara 0.1-0.15 $\mathrm{cm}$ sesuai dengan ketebalan botol. Prosedur pembuatan tali plastik dapat dilihat pada Gambar 8 .

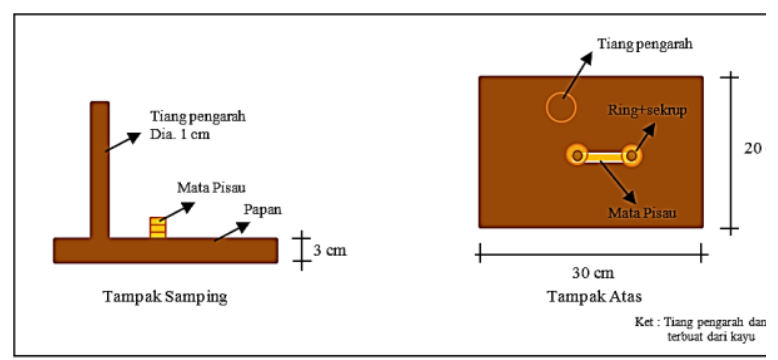

Gambar 7. Alat pemotong botol plastik

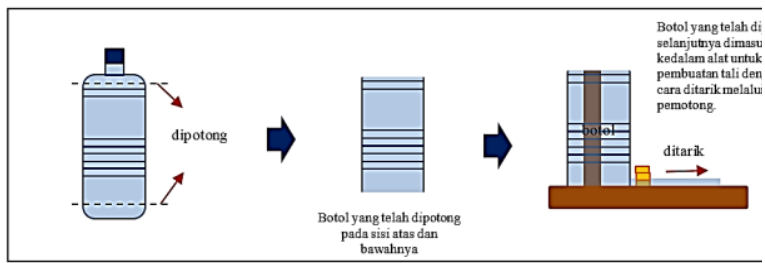

Gambar 8. Prosedur pembuatan tali platik

\section{Perakitan Plasticnet}

Science and Technology

Perakitan tali botol plastik dilakukan seperti tahapan yang telah dijelaskan pada Gambar 2 . Berikut tahapan proses perakitan Plasticnet.

1. Meyiapkan platform persegi sebagai landasan untuk perakitan yang terbuat dari balok kayu

2. Memotong tali plastik dengan panjang $3 \mathrm{~m}$ untuk arah vertikal dan $4 \mathrm{~m}$ untuk arah horisontal

3. Tali yang sudah terpotong selanjutnya disusun pada arah vertikal (tali di paku) sesuai dengan jarak yang telah ditentukan yaitu $3 \mathrm{~cm}$.

4. Perakitan dimulai dari arah horisontal (kiri ke kanan) dengan menganyam setiap helai tali dari arah vertikal.

Dokumentasi proses perakitan tali botol plastik menjadi Plasticnet dapat dilihat pada Gambar 9 berikut.

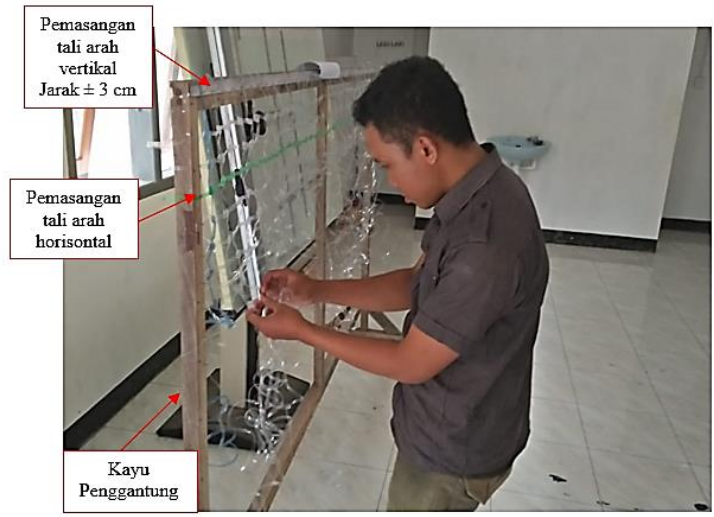

Gambar 9. Proses perakitan tali menjadi plasticnet

\section{Penghamparan Material}

Material plasticnet yang sudah dirakit kemudian dihamparkan pada lokasi rencana jalan raya dengan susunan seperti pada Gambar 10.

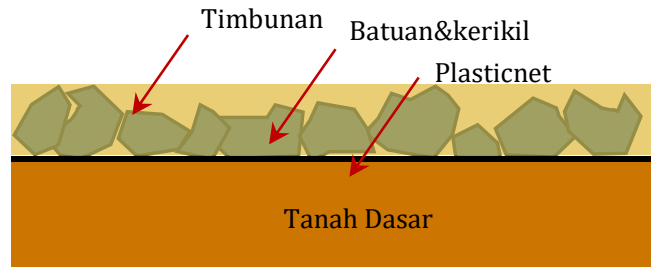

Gambar 10. Susunan Lapisan Perkerasan

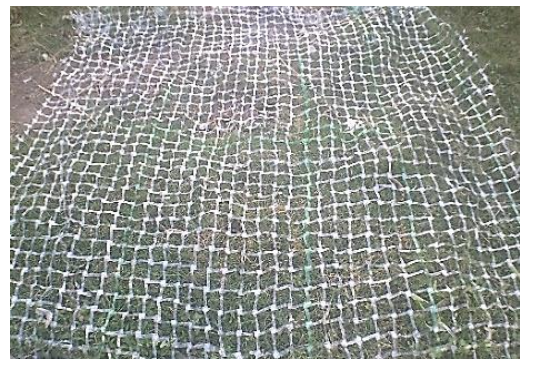

Gambar 11. Plasticnet diatas tanah dasar 
JURNAL TAMBORA VOL. 3 NO. 2 JUNI 2019

Sttp://jurnal.uts.ac.id

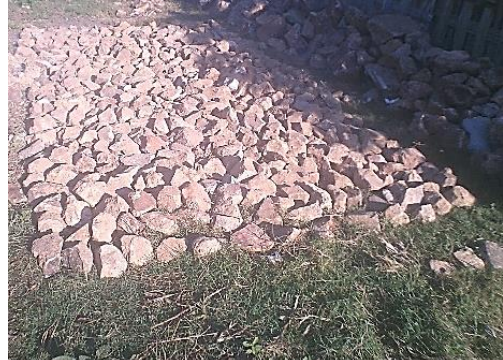

Gambar 12. Batu dan kerikil diatas plasticnet

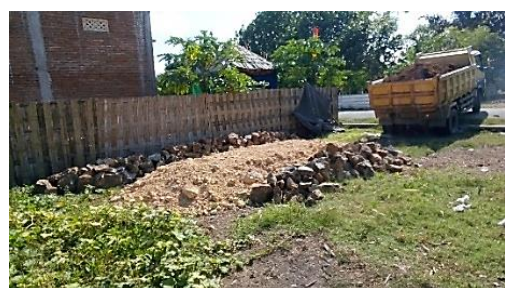

Gambar 13. Timbunan diatas batuan dan kerikil

\section{Pengujian Plasticnet}

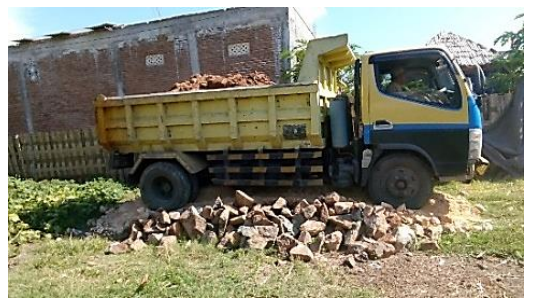

Gambar 14. Proses Pengujian mengunakan beban kendaraan

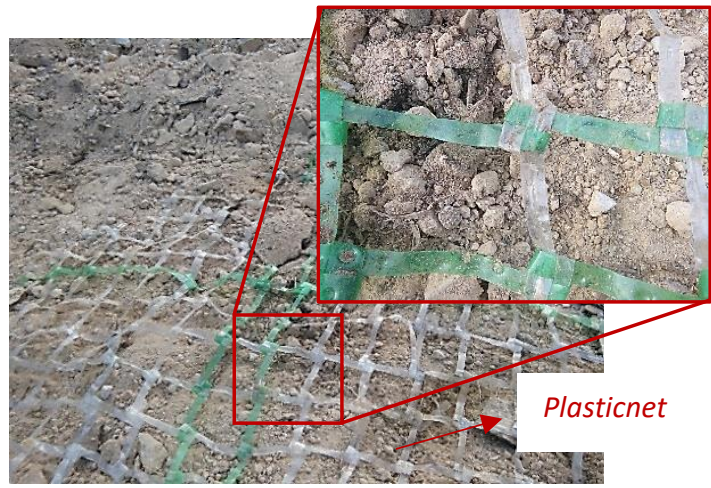

Gambar 15. Tampak Fisik Plasticnet setelah di Uji

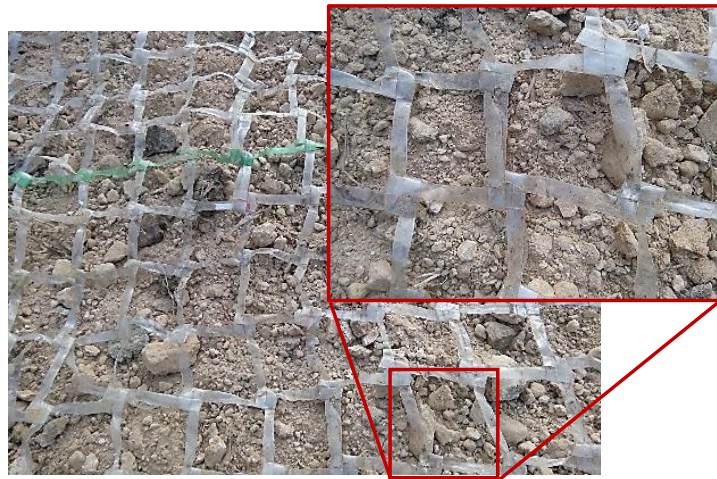

Gambar 16. Tampak Fisik Plasticnet setelah di Uji
Berdasarkan informasi yang ditampilkan pada Gambar 14 dan Gambar 15 menunjukkan bahwa secara fisik material ini cukup baik dengan melihat tidak ditemukan robek yang signifikan pada plasticnet yang disebabkan oleh beban baik beban kendaraan beserta muatan maupun akibat material batu dan kerikil yang dijatuhkan dari truk pada saat dilakukan penimbunan dan pemadatan.

\section{PENUTUP}

\section{Kesimpulan}

Hasil yang diperoleh dari penelitian ini dapat disimpulkan sebagai berikut:

1. Metode perbaikan tanah menggunakan plasticnet dilakukan setelah lapisan tanah dasar, sehingga material ini dapat menjadi bahan pemisah dari batu pecah dan juga timbunan yang ada diatasnya. Disamping itu, dengan penambahan plasticnet ini dapat memberikan tambahan perkuatan pada lapisan perkerasan.

2. Berdasarkan hasil simulasi kekuatan tarik menggunakan software Ansys diperoleh deformasi total sebesar $0.015294 \mathrm{~m}$, Maximum Shear Elastic Strain sebesar $0.01112 \mathrm{~m} / \mathrm{m}$ dan Maximum Shear Stress sebesar 1.2497e7 Pa yang mengindikasikan bahwa bahan ini memungkinkan untuk digunakan sebagai bahan baku dalam pembuatan plasticnet.

3. Hasil pengujian lapangan pada bahan plasticnet menunjukkan bahwa secara fisik tidak ada kerusakan dan robek yang signifikan baik akibat beban dari batu maupun dari timbunan dan beban kendaraan yang diterapkan. Sehingga material ini dapat digunakan sebagai alternatif dalam perkuatan dan separasi pada jalan raya khususnya di daerah terpencil.

\section{Saran}

Saran dari penelitian ini adalah sebagai berikut:

1. Khusus untuk plasticnet, perlu dilakukan uji tarik, uji robek dan uji ketahanan bahan dengan menggunakan alat uji yang biasa digunakan pada pengujian bahan-bahan geosintetik.

2. Perlu dipikirkan alat anyam yang dapat meminimalisir waktu pengerjaan dan jumlah personil yang dibutuhkan selama perakitan.

\section{REFERENSI}

Al-Salem, S. M., Lettieri, P., Baeyens, J. (2009), Recycling and recovery routes of plastic solid waste (PSW): A review. Waste Management .,29, 2625-2643.

ASTM D-638, Standard Test Method for Tensile Properties of Plastic. USA.

Aye, L. and Widjaya, E. R. (2006), Environmental and economic analyses of waste disposal options for traditional markets in Indonesia, Waste Management. Volume 26, Issue 10., 1180-1191. 
Bappeda Prov. NTB bekerjasama dengan BPS Prov. NTB, (2015), Nusa Tenggara Barat dalam Data, CV. Harapan Mandiri Utama, Mataram.

Fluet, J. (1988), Geosynthetics for Soil Improvement: A General Report and Keynote Address, Geosynthetics for Soil Improvement, Edited by Holtz, R.D, ASCE.

Guiqing Wu, Jia Li, Zhenming Xu. (2013), Triboelectrostatic separation for granular plastic waste recycling : A review. Waste management .,33, 585-59.

Hardiyatmo, H. C. (2013), Geosintetik untuk Rekayasa Jalan Raya Perancangan dan Aplikasi, Gadjah Mada University Press, Yogyakarta.

Industrial Fabric Association International (IFAI), (1992), Geosynthetics, IFAI, USA.

Kementerian Negara Lingkungan Hidup (KNLH) Republik Indonesia (2008), Statistik Persampahan Indonesia, KNLH, Jakarta.

Kementerian Pekerjaan Umum dan Perumahan Rakyat (PUPR) (2015), Informasi Statistik Infrastruktur, PUPR, Jakarta.

Mitchell, James, K. (1981), Soil Improvement: State of Art, State of the Art Report, Session 12, Proceedings of the Tenth International Conference on Soil Mechanics and Foundation Engineering, Stockholm, Sweden, June 15-19.

Mochtar, Indrasurya B. (1990), Geosintetik Masa Kini, Proseding Seminar Geosintetik Masa Kini Himpunan Mahasiswa Sipil Institut Teknologi Sepuluh Nopember (ITS), 19 Mei 1990.

Nkwachukwu, O. I., Chima, C. H., Ikenna, A. O., Albert, L. (2013), Focus on potential Environmental issues on plastic world to wards a sustainable plastic recycling in developing countries, International Journal of Industrial Chemistry., 4, 34

Pilarczyk, K. W. (2000), Geosynthetics and Geosystems in Hydraulic and Coastal Engineering, A.A. Balkema, Rotterdam, Netherlands.

Richardson, G. N. ad Koerner, R. M. (1990), A Design Primer: Geotextiles and Related Materials, Industrial Fabrics Association International, St. Paul, 104 pp.

Samawarea (2016), Wakil Rakyat Prihatin Sampah Berseliweran di Tepi Jalan. http://www.samawarea.com/2016/01/wakilrakyat-prihatin-sampah-berseliweran-di-tepijalan/. Diakses pada 04 Juni 2017

Wilson, D. C., Velis C., Cheeseman C. (2006), Role of Informal Sector Recycling in Waste Management in Developing Countries, Habitat International., 30, 797-808. 